\title{
ランダム配向不連続炭素䋊維強化ガラス基複合材料の破壊メカニズム†
}

\author{
武 田 展 雄* \\ P. G. Karandikar *** \\ 黄 木 景 二** \\ K. M. Prewo ${ }^{* * *}$
}

\section{Fracture Mechanism in Randomly Oriented Discontinuous Carbon Fiber Reinforced Borosilicate Glass Matrix Composites}

\author{
by \\ Nobuo TAKeda*, Keiji OGI ${ }^{* *}$, Prashant G. KarandiKar ${ }^{* * *}$ \\ and Karl M. PREWo ***
}

\begin{abstract}
Fracture mechanisms in randomly oriented discontinuous carbon fiber reinforced borosilicate glass matrix composites are experimentally characterized. Two types of composite specimens with identical constituents but different microstructure were produced. The first type shows the three-stage behavior in the tensile stress-strain curve. In the second type which has the initial cracks, the stress - strain response is almost linear, but the initial Young's modulus is lower than that of the first type. Monotonic and static cyclic tensile and four point bend tests are conducted on those two specimens to measure the microcrack density, Young's modulus and Poisson's ratio as a function of applied strain. The experimentally determined crack density is used to estimate the interfacial shear stress. In the bend tests, evolution of microcracking on the tensile surface and through the thickness has been studied. Acoustic emission (AE) during the tests is monitored to understand the fracture mechanisms. It is proved that the difference in fracture mode between the two specimens is due to the difference in microstructure and the presence of initial defects. The $\mathrm{AE}$ behavior shows good correlation with the evolution of microcracking and can explain the fracture processes. Young's modulus can be a damage parameter to estimate the microcrack density. Microcracking during the flexural tests begins on the tensile surface and the cracks progress gradually towards the neutral axis.
\end{abstract}

Key words : Discontinuous fiber, Glass matrix composite, Fracture mechanism, Matrix cracking, Acoustic emission

\section{1 緒}

繊維強化セラミックス，または繊維強化耐熱ガラスは， マトリックス単体と比べて高い機械的強度とじん性が得 られるため，ジェットエンジンや発電機用ガスタービンの 耐熱材料として注目されている.これら複合材料の信頼 性向上のためには, 破壊プロセスと破壞メカニズムの理 解が不可欠であり，これまでに様々な研究がなされてい る.1)特に, 繊維強化セラミックス (ガラス) の破壊プロ セスに関する非破壊的な研究としては, レプリカ法,2, 3) 顕微鏡を用いた它の場観察，年（7)アコースティック・エミ ッション (Acoustic Emission; AE) 測定 ${ }^{8), 9)}$ な゙゙が行わ れている.

以上は主に一方向繊維強化セラミックスに関する研究 であるが，一方，ランダム配向不連続炭素䋐維強化ガラ 又基複合材料（Carbon Fiber/Borosilicate Glass ; $\mathrm{CF} / \mathrm{BSG}$ ) が高柔軟性, 高じん性を持つことが Prewo ${ }^{10)}$ により示されている。このような高じん化はマトリック スき裂と繊維マトリックス界面のはく離・摩擦によると 考えられ， $\mathrm{AE}$ 測定と超音波顕微鏡气の場観察による微 視的破壊メカニズムのモデリング11) 13)がなされている.
しかしながら，機械的特性の変化，および $\mathrm{AE}$ 特性と破 壊プロセスの関係が十分に明らかにされていない。

そこで本研究では, 成形条件の違う二つの $\mathrm{CF} / \mathrm{BSG}$ 試験片について，単調引張，準静的負荷/除荷，および 四点曲げ試験を行い，機械的特性と破壊メカニズムを調 ベた. 単調引張試験に扔いて応力一ひずみ曲線 (ヤング 率とポアソン比) と $\mathrm{AE}$ データ（累積 $\mathrm{AE}$ 事象数, 振幅 分布）を取得した。準静的負荷/除荷試験では，負荷を 中断して損傷のレプリカをとった後，除荷を行い，き裂 密度，および除荷ヤング率を求めた。 き裂密度から界面 せん断応力を計算し, 破壊プロセスの違いを検討した。 一方, 四点曲げ試験において, 単調負荷中の $\mathrm{AE}$ データ を取得し，別の試験片で負荷途中の引張側表面と側面の レプリカをとり損傷進展の様子を調べた。 以上の実駼か ら, CF/BSG の微視構造と機械的特性の関係, および 応力一ひずみ線図・ $\mathrm{AE}$ 特性と破壞プロセスの関係を明 らかにするとともに，ヤング率・ポアソン比の損傷パラ メータとしての有意性を検討した。

\section{2 実 験 方 法}

\section{$2 \cdot 1$ 材料}

原稿受理 平成 9 年 8 月18日 Received Aug. 18, 1997

* 正 会員 東京大学国際・産学共同研究センター テ153-8904 東京都目黒区駒場, Center for Collaborative Res., The Univ. Tokyo, Meguro-ku, Tokyo, 153-8904

** 正 会 員 九州大学応用力学研究所 $\bar{T} 816-8580$ 春日市春日公園, Res. Inst. for Applied Mech., Kyushu Univ., Kasuga-koen, Kasuga, 816-8580

*** ） デラウェア大学, Univ. of Delaware, Newark, DE 19716, USA

**** ユナイテッド・テクノロジーズ・リサーチセンター, United Tech. Res. Center, East Hartford, CN 06108, USA 
強化材として面内ランダム配向した不連綂炭素繊維 （長さ $19 \mathrm{~mm}$, 直径約 $8 \mu \mathrm{m}$ ) から成るシートを用い, ボロシリタートガラス粉末のスラリー中を通した後，乾 懙後, 樍層与る。次に, 圷力 $6.9 \mathrm{MPa}$, 温度 $1200^{\circ} \mathrm{C}$ 以 上の条件でホットプレスを施し， $150 \mathrm{~mm} \times 150 \mathrm{~mm} \times 2$ 〜 $8 \mathrm{~mm}$ の複合材料板を作製した。紪維は 2 次元ランダ ムに配向しており，多少の繊維の束は見られるが，ほぼ 分離されている。繊維体積含有率は 30〜35\%, 空孔体 積率は 1 3\%である。成形温度の異なる二種類の CF/BSG 複合材料板（Plate 634, Plate 611）を作製した。 Fig. 1 に二種類の複合材料板の微視構造の電子顕微鏡写 真を示す. Plate 634 には多少の埮孔が見られるが，き 裂は存在しない. Plate 611 は成形温度が Plate 634 より 高いため, 微小なマトリックスき裂がランダムに存在す る. Table I に複合材料（Plate 634）と構成材料の材料 定数を示す。複合材料のヤング率はマトリックス単体の 林小さい。
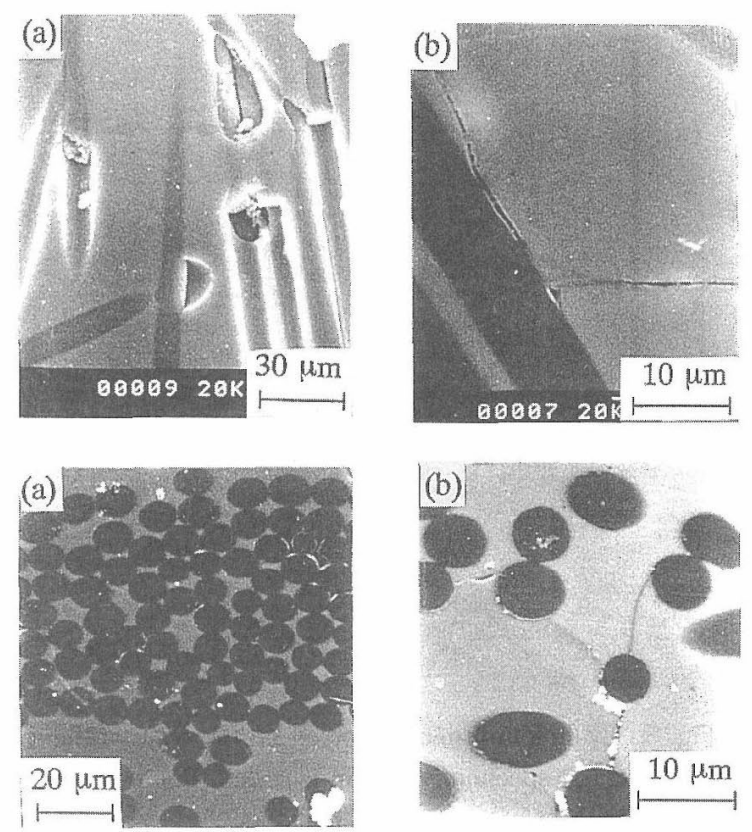

Fig. 1. Microstructure of randomly oriented discontinuous carbon fiber reinforced glass matrix composites for the (a) Plate 634 and (b) Plate 611.

Table I. Properties of a composite (Plate 634) and constituent materials.

\begin{tabular}{l|c|c|c|c|c}
\hline & $\begin{array}{c}\text { Elastic } \\
\text { modulus, } \\
\mathrm{GPa}\end{array}$ & $\begin{array}{c}\text { Density, } \\
\mathrm{g} / \mathrm{cm}^{3}\end{array}$ & $\begin{array}{c}\text { Thermal } \\
\text { expansion, } \\
10^{-6} \mathrm{~K}\end{array}$ & $\begin{array}{c}\text { Thermal } \\
\text { conductivity, } \\
\text { W/m } 3 \mathrm{~K}\end{array}$ & $\begin{array}{c}\text { Specific } \\
\text { heat, } \\
\mathrm{J} / \mathrm{kg} / \mathrm{K}\end{array}$ \\
\hline $\begin{array}{l}\text { Composite } \\
\text { in plane } \\
\text { normal to plane }\end{array}$ & 28 & 2.09 & $\begin{array}{c}1.7 \\
4.2\end{array}$ & $\begin{array}{c}>1.04 \\
1.04\end{array}$ & 752 \\
\hline $\begin{array}{c}\text { Borosilicate } \\
\text { Carbon fiber } \\
\text { axial } \\
\text { radial }\end{array}$ & 63 & 2.23 & 3.25 & - & 780 \\
\hline
\end{tabular}

\section{$2 \cdot 2$ 負荷試験と $\mathrm{AE}$ 測定}

単調引張, 準静的負荷/除荷, および四点曲げ試験はイ ンストロン万能試験機を用いて, クロスヘッドスピード $0.1 \mathrm{~mm} / \mathrm{min}$.で行った。単調引張，準静的負荷/除荷試 験には $150 \mathrm{~mm} \times 10 \mathrm{~mm} \times 3 \mathrm{~mm}$ または $150 \mathrm{~mm} \times 10 \mathrm{~mm}$ $\times 5 \mathrm{~mm}$ ，四点曲げ試験には $75 \mathrm{~mm} \times 5 \mathrm{~mm} \times 3 \mathrm{~mm}$ の大 きさの試験片を用いた。四点曲げ試験の外スパンは 60 $\mathrm{mm}$, 内スパンは $20 \mathrm{~mm}$ とした。揁傷のレプリカをとる ために，試験片の片方の表面と側面を研磨した。引張試 験片の両端にはガラス/エポキシのタブ（長さ $45 \mathrm{~mm}$, テーパー $20^{\circ}$ ) を接着した。ひずみゲージ（ゲージ長さ 5 mm）により, 引張試験片の縦方向・横方向のひずみ，打 よび四点曲げ試験片の引張面・圧縮面の長于方向ひずみ を測定した。引張，および四点曲げ試験片のゲージ部両 端に $\mathrm{AE}$ センサー( $\mathrm{PAC}$ pico) を接着し， $\mathrm{PAC} 3000 / 3104$ システムを用いて $\mathrm{AE}$ 測定を行い，試験終 了後に解析を行った（Fig. 2).プリアンプ，メインアン プのゲインはをれ穵れ $40 \mathrm{~dB} ， 20 \mathrm{~dB}$ ，しきい值は $0.1 \mathrm{~V}$, デッドタイムは $0 \mu \mathrm{sec}$ を選んだ。二つのセンサー間（引 張試駰：40 mm, 曲げ試験：60 mm）以外から発生した $\mathrm{AE}$ ，扣よびノイズはフィルタリングにより除去した。

単調引張試験では, 応力 - ひずみ線図からヤング率と ポアンン比を計算するとともに, 累積 $\mathrm{AE}$ 事象数, 振幅 分布を求めた。準静的負荷/除荷試験では，いくつかの荷 重段階で負荷を中断して損傷のレプリカをとった後，完 全除荷と再負荷を行った。レプリカはアセテートフィル

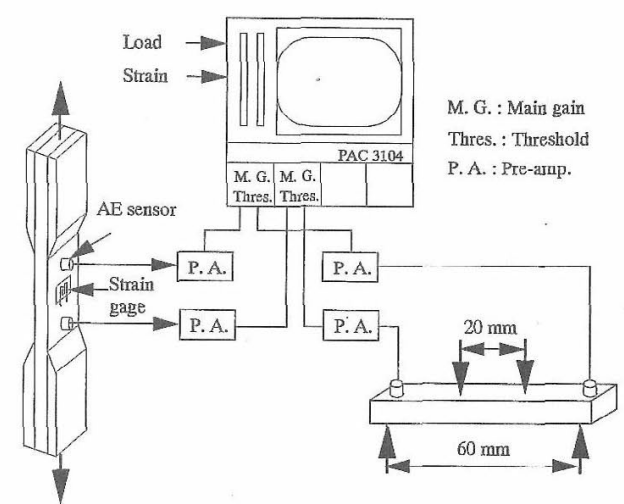

Fig. 2. Date acquisition system for stress-strain and acoustic emission measurements.

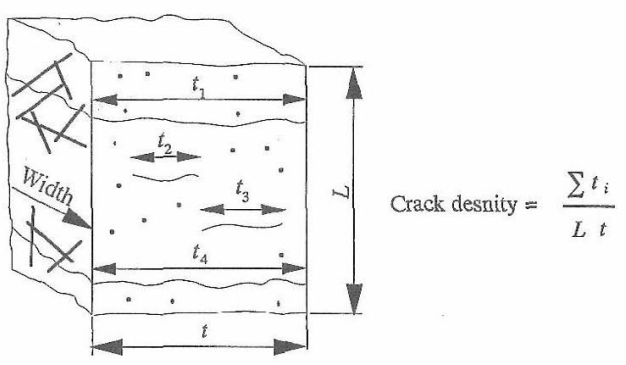

Fig. 3. Crack density calculation method. 


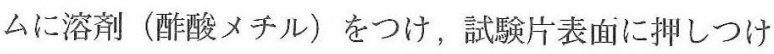
ることにより作製した。き裂密度はFig. 3 に示すように単 位長さあたりに発生する試験片厚さ厅向に買通するき裂 の個数で定義した.ただし，貫通していないき裂は $t_{i} / t$ 個と数えた。また，除荷ヤング率を計算し，き裂密度と の相関を調べた。四点曲げ試験でも引張試験と同様にし

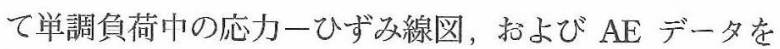
取得した。別の四点曲げ試験片では，負荷途中の引張側 表面と側面のレプリカをとり損傷進展の様子を調べた。

\section{3・ 1 引張試験}

\section{3 実 験 結 果}

Fig. 4 に Plate 634,611 の引張応力一縦ひずみ，およ び引張応力一横ひずみ線図を示す。Plate 634 試験片で は, 応力一ひずみ曲線が次の 3 つの領域に分けられる。 （I）初期変形領域 $(0 \sim 0.12 \%)$ ，（II）擬降伏領域 $(0.12 \sim 0.3 \%)$, (III) 最終変形領域 $(0.3 \% \sim)$. 領域 T の 線形部分のヤング率は $44.6 \mathrm{GPa}$ である。縦ひずみが 0.08\%を越えると応力一ひずみ曲線に非線形が現れる。 領域 IIでは，応力がほぼ一定のまま縦ひずみと横ひずみ が増大するため，曲線の傾きが減少する。縦ひずみが 0.3 \% に達すると（領域四）再び傾きが上昇し始め，ほぼ線

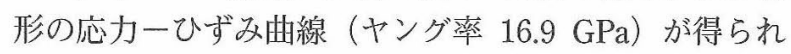
る。一方 Plate 611 試験片では, 顕著な屈曲点が見られ ず，曲線の傾きが連続的に減少している。初期ヤング率 は $35.1 \mathrm{GPa}$ ，最終ヤング率は $20.3 \mathrm{GPa}$ である。

Fig. 5，Fig. 6 にそれぞれ Plate 634, Plate 611 試験片 の側面の損傷進展のレプリカ写真を示す. Plate 634 に おいて応力とひずみの組み合わせの值が Fig. 4 と正確に

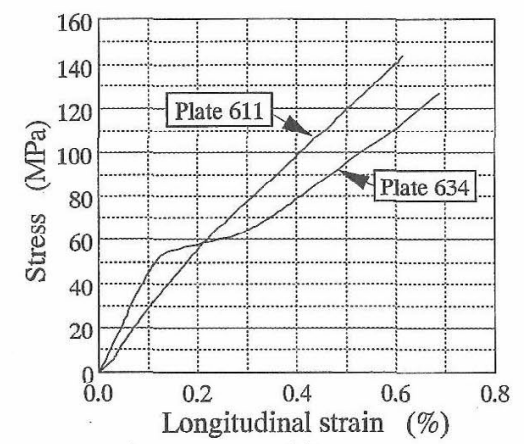

(a)

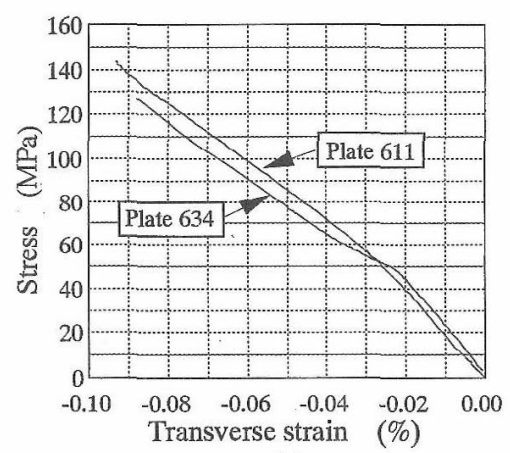

(b)

Fig. 4. Stress-(a) longitudinal, (b) transverse strain curves for the Plate 634 and Plate 611 specimens.
一致しないのは，負荷/除荷の影響により応力一ひずみ 曲線が Fig. 4 と比べて右側にシフトするためである。負 荷レベルの増大に伴い，マトリックスき裂密度は増大す る（Fig. 7)。繊維はランダムに配向されているが，マト
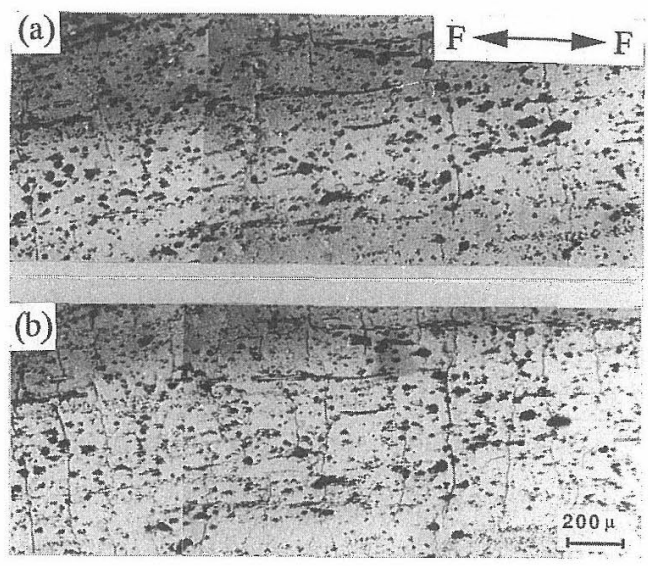

Fig. 5. Evolution of microcracking on the edge of the Plate 634 specimen at strain (stress, MPa) level (a) $0.15 \%(50.3)$ and (b) $0.76 \%$ (121.7).
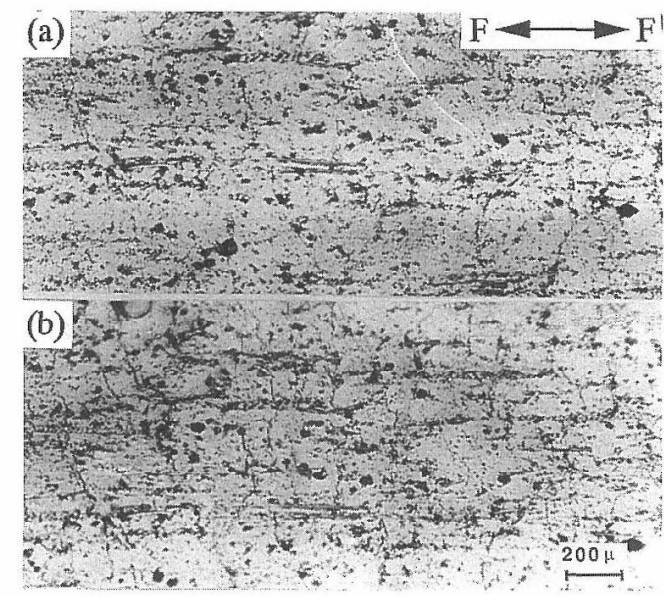

Fig. 6. Evolution of microcracking on the edge of the Plate 611 specimen at strain (stress, MPa) level (a) $0.27 \%(71.5)$ and (b) $0.47 \%(112.2)$.

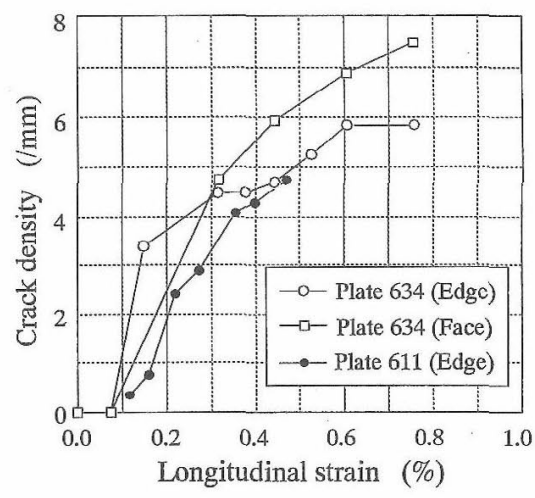

Fig. 7. Crack density as a function of longitudinal strain for the Plate 634 and Plate 611 specimens under the tensile tests. 
リックスき裂は荷重方向に対して横方向にしか発生しな い. 二種類の試験片では，き裂の様相と進展挙動が異な っている。すすおち，Plate 634 では，き裂は直線的で䋊 維/マトリックス界面を通るものは少ないが, Plate 611 では，き裂はジグザグであり，成形による初期き裂と界 面を結合するように進展している。また，Plate 634 では き裂密度が領域 II において急激に増加するのに対して， Plate 611 では徐々に増加している. 両試験片ともに表 面におけるき裂密度が側面より少し高い，これは表面に 発生しだ裂のうち，10％程度が試験片幅全体にわたつ ていないためである.

Fig. 8 に単調引張試験中の各負荷段階に打ける $\mathrm{AE}$ 振 幅分布を示す. Plate 634 の場合, 40-60 MPa の応力範囲 に扎いて 60-80 dB の中振幅AEが発生しているが，60-80 $\mathrm{MPa}$ では少量の中振幅 $\mathrm{AE}$ しかみられない. 100-120 $\mathrm{MPa}$ の範囲では，70-90 dB の高振幅 $\mathrm{AE}$ が数多く見られ る. 一方, Plate 611 の場合, 40-60 MPa, $60-80 \mathrm{MPa}$ と もに 45-60 dB の低振幅 $\mathrm{AE}$ が発生しているが，120-140 $\mathrm{MPa}$ では 45-90 dB の広い振幅範囲の $\mathrm{AE}$ が発生してい る. Fig. 9 に累積 $\mathrm{AE}$ 事象数の変化を示す. $\mathrm{AE}$ 発生の開
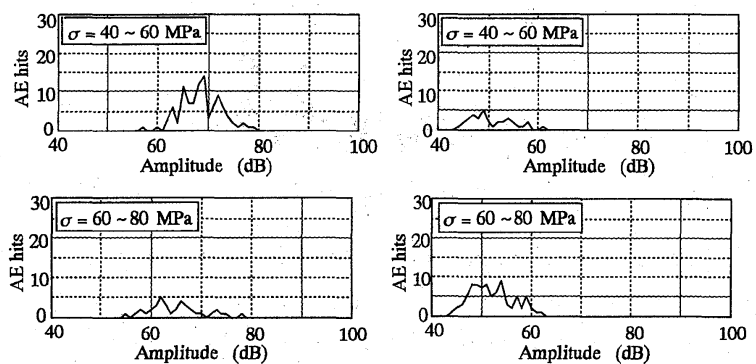

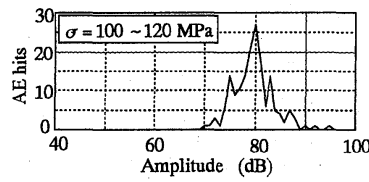

(a)

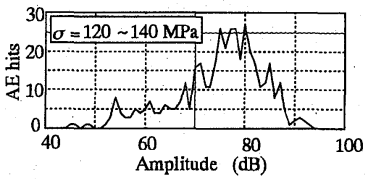

(b)
Fig. 8. Variation of $\mathrm{AE}$ amplitude distribution for the (a) Plate 634 and (b) Plate 611 specimens under the tensile tests.

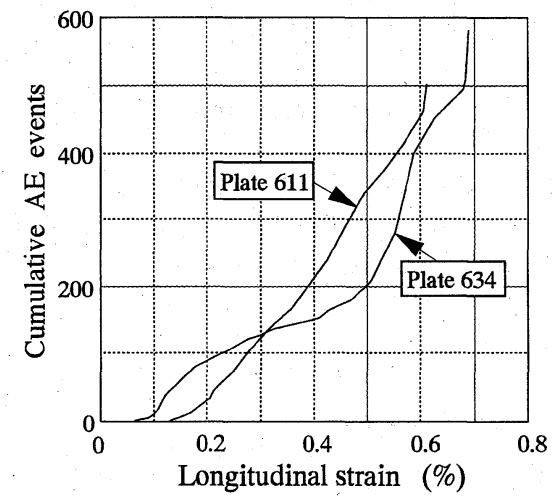

Fig. 9. Cumulative $\mathrm{AE}$ events as a function of longitudinal strain for the Plate 634 and Plate 611 specimens under the tensile tests.
始点のひずみは, Plate 634 では 0.067 \%（応力 29.6 $\mathrm{MPa})$ であるのに対し, Plate 611 では $0.13 \%(37.6$ $\mathrm{MPa})$ であり Plate 634 より高い. また Plate 634 では $\mathrm{AE}$ 発生開始後，事象数が増加するが，0.2 0.4\%のひず み範囲で増加率が一旦低下した後，再び急激な増加を示 す。一方, Plate 611 では, $\mathrm{AE}$ 発生から破断まで $\mathrm{AE}$ 事 象数の増加率はほぼ一定である。

準静的負荷/除荷試験の応力一ひずみ線図では，き裂 の発生した高応力において顕著なヒステリシスがみられ た. 従って, 除荷曲線の初めの部分と終わりの部分をそ れぞれ初期除荷，最終除荷と呼ぶことにし，初期除荷， 最終除荷のヤング率を計算した. Fig. 10 に Plate 634, 611 試験片の除荷ヤング率の変化を示す。両試験片とも に, 縦ひずみ $0.1 \%$ 以上で除荷ヤング率の減少が見られる. 初期除荷ヤング率, 最終除荷ヤング率の飽和值は, Plate 634 ではそれぞれ $28 \mathrm{GPa}, 17 \mathrm{GPa}$, Plate 611 ではそれぞ れ $28 \mathrm{GPa} ， 25 \mathrm{GPa}$ である. Fig. 7, Fig. 10 を用いて除荷 ヤング率の低下量をき裂密度に対してプロットしたもの を Fig. 11 に示す．実線は初期除荷ヤング率の最小二乗 近似直線である. Fig. 12 に単調引張試験 (Fig. 4) から 得られたポアソン比一縦ひずみ線図を示す. Plate 634 では初期ポアソン比が 0.2 であり, 少し増加した後, 急 激に減少して, 最終值 0.13 に落ちつくが, Plate 611 では, 初期ポアソン比 0.15 のまま変化しない.

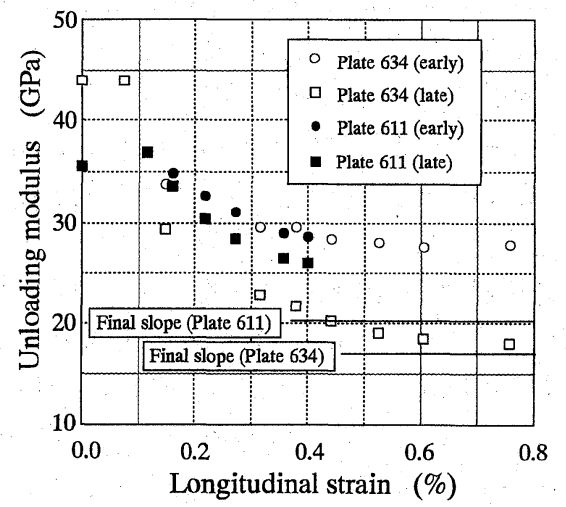

Fig. 10. Variation of unloading Young's modulus for the Plate 634 and Plate 611 specimens as a function of applied strain.

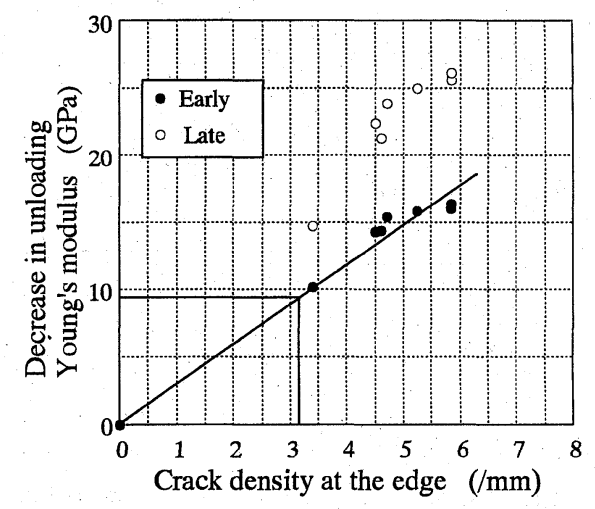

Fig. 11. Decrease in unloading Young's modulus against microcrack density for the Plate 634 specimens. 


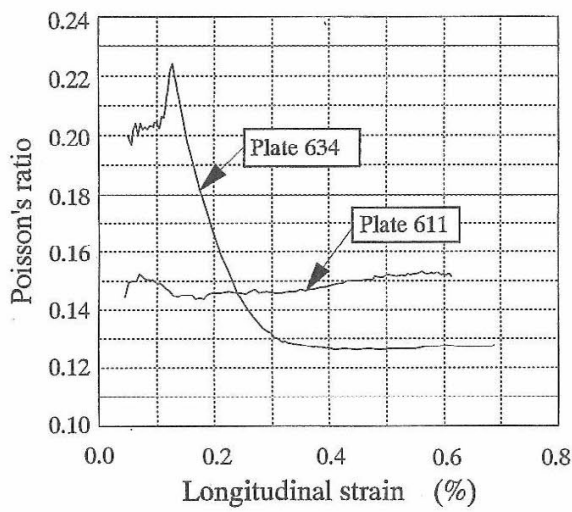

Fig. 12. Variation of Poisson's ratio as a function of applied strain for the Plate 634 and Plate 611 specimens under the tensile tests.

\section{$3 \cdot 2$ 四点曲げ試験}

Fig. 13 にPlate 634，611 の四点曲げ試験におるける引張 面と压縮面の応力一ひず応答を示す。応力はき裂によ るヤング率の変化を考虑せずに弾性はり理論を用いて計 算した。 Plate 634，611 の引張および圧縮面の初期ヤン グ率は 42〜45 GPa である.Plate 634，611 ともに圧縮面 の応力ーひず線図は $0.1 \%$ 付近で屈曲し，ヤング率が 低下している。Plate 611 の引張面の応力一ひずみ線図 は引張試験と同様に連続的にヤング率が低下しているが, Plate 634 の引張而の応力一ひず線図は領域】のヤン グ率が引張試験のものと比べて高い。

曲げ試験片断面のき裂進展の様子，扣よび，き裂の引

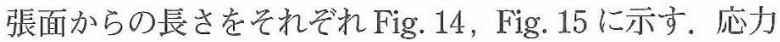
の増加に伴い，き裂数，き裂長さともに増加する。破断 近くの応力では，多くのき裂が中立軸まで進展する。 Fig. 16 に累積 $\mathrm{AE}$ 事象数の变化を示す。引張試験の場合 (Fig. 9) と異なり, Plate 634 では, AE 事象数の増加率 が低下する領域が見られず，Plate 611 の AE 事象数は Plate 634 より多い。破断前の $\mathrm{AE}$ の急激な増加は, 圧縮 側荷重点の下での層間はく離に対応している。

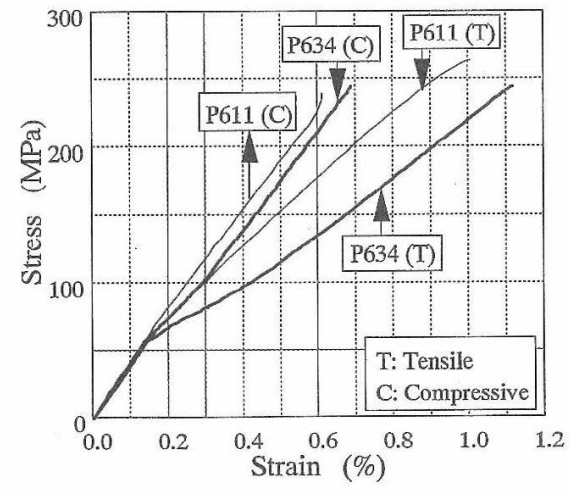

Fig. 13. Tensile and compressive stress-strain curves of the four-point bend tests for the Plate 634 and 611 specimens. Absolute values are used in the compressive curves.

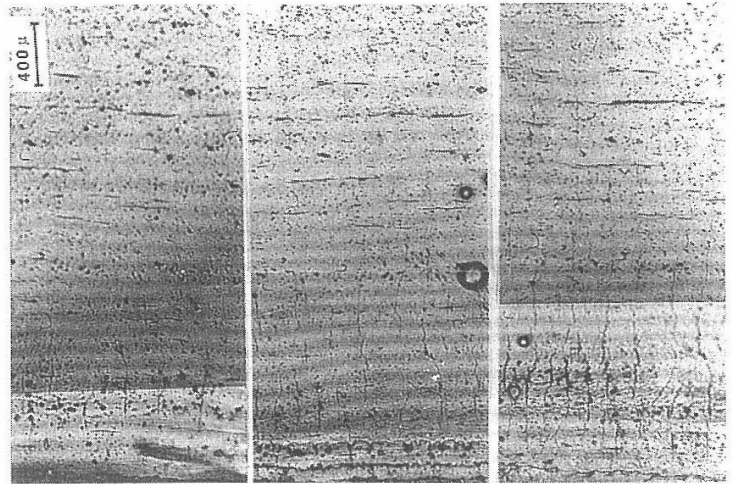

Fig. 14. Progression of matrix cracking from the tensile (bottom) to the compressive side under the fourpoint bend tests of Plate 634 at strain (stress, MPa) (a) $0.30 \%$ (85), (b) $0.63 \%(149)$ and (c) $0.97 \%(228)$.
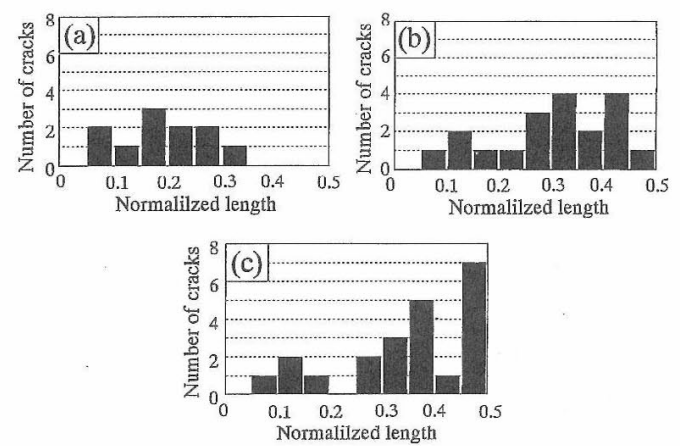

Fig. 15. Normalized crack length from the tensile surface during the four-point bend tests of Plate 634 at strain (stress, MPa) (a) 0.30\% (85), (b) $0.63 \%$ (149) and (c) $0.97 \%(228)$

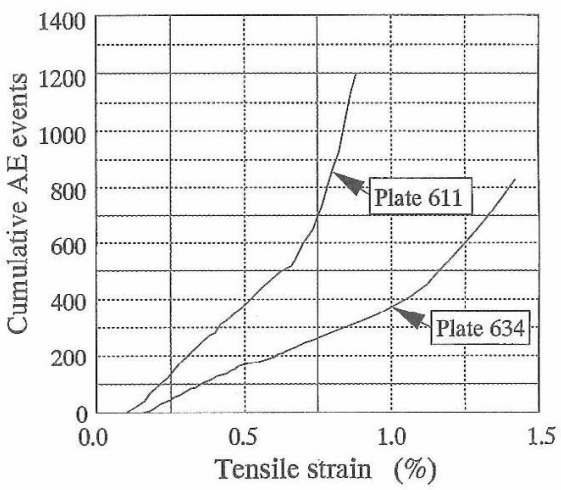

Fig. 16. Change in cumulative $\mathrm{AE}$ events against tensile strain for the Plate 634 and 611 specimens under the four-point bend tests.

\section{4 考察}

\section{$4 \cdot 1$ 微視構造と材料特性}

本研究の材料では繊維長 $(19 \mathrm{~mm})$ が臨界繊維長 (2 $\mathrm{mm}$ 程度）と比べて十分に長いため, 力学的には 2 次元 ランダム連続繊維強化複合材料と等価であるとみなし 議論する。 
炭素繊維の軸方向の熱膨張率は負であり，ママトリック スの熱膨張率とのミスマッチが大きい，それ故，繊維方 向にはマトリックスに引張の熱残留応力が発生する. Plate 611 では Plate 634 より成形温度と成形圧力が高い ため，空孔が見られないかわりに，初期き裂がランダム な方向に発生している (Fig. 1). このため Plate 634 と比 ベて Plate 611 の方が初期ヤング率が低い. また半径方向 には繊維の方が熱膨張率が大きい（Table I）ため, 冷 却プロセス時に繊維が縮み, 界面がはく離していること が予想される. 2 次元ランダム繊維強化複合材料に対す るヤング率は次式で表される. ${ }^{10)}$

$$
E_{c}=\frac{3}{8} E_{L}+\frac{5}{8} E_{T}
$$

ここで, $E_{L}, E_{T}$ は一方向板の繊維方向, 横方向の弾 性率である. 複合則より得られる $E_{L}=123 \mathrm{GPa}, E_{T}=$ $85 \mathrm{GPa}$ を式 (1) に代入すると， $E_{C}=99 \mathrm{GPa}$ が得られる.

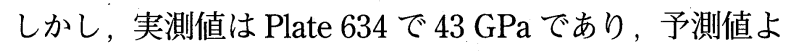
りかなり小さい. これは界面のはく離によるものと考え られ, 界面のはく離を考慮した修正複合則 ${ }^{13)}$ が必要であ る. 界面が接着されていない 2 次元ランダム強化複合材 料の界面せん断応力は次式より計算される. ${ }^{14), 15)}$

$$
\tau=\frac{\pi}{2} \frac{1-V_{f}}{V_{f}} \frac{\sigma_{m u} r}{2 S}
$$

ここで， $V_{f}, \sigma_{m u}, r, S$ はそれぞれ繊維体積含有率, マトリックスの強度, 繊維半径, き裂間隔である. 領域 II の初めのひずみをマトリックスの平均破断ひずみと仮定し て $\sigma_{m u}=75.6 \mathrm{MPa}\left(\varepsilon_{m u}=0.12 \%\right)$ とし, $V_{f}=0.3, r=$ $4 \mu \mathrm{m}$, および実験值 $S=172 \mu \mathrm{m}$ を式 (2) に代入すると, $\tau=$ $3.2 \mathrm{MPa}$ が得られる. このように界面せん断応力が非常に 小さいことがヤング率の低さと次節で述べるき裂進展挙動 に影響する。

\section{$4 \cdot 2$ き裂進展挙動}

引張試験（Fig. 4), および四点曲げ試験 (Fig. 13) の引 張応力一ひずみ応答はマトリックスき裂の発生により説明 される. Plate 634 の場合, 領域 Iにおいてヤング率, ポア ソン比ともに一定でき裂, $\mathrm{AE}$ ともに発生しない. 領域I で見られるひずみ増加は試験片幅全体にわたる多重き裂の 発生による.この際のひずみ増分は次式で表される. ${ }^{14), 15)}$

$$
\Delta \varepsilon_{c}=\frac{E_{m}\left(1-V_{f}\right)}{2 k E_{f} V_{f}} \varepsilon_{m u}
$$

ここで $E_{f}, E_{m}$ はそれぞれ繊維，マトリックスのヤン グ率, $k$ の值は 2 次元ランダム配向の場合, 約 0.25 であ る. ${ }^{16)}$ 式 (3) に值を代入すると $\Delta \varepsilon_{c}=0.15 \%$ が得られ，ほぼ 実験值と一致する. 領域IIIでは一定のヤング率で破断ま で変形するがき裂密度がほぼ飽和している (Fig. 7). 一 方, Plate 611 の場合, ランダムに分布する初期き裂が 繊維/マトリックス界面と結合しながら進展するため, ヤ ング率が徐々に減少していく，このことは Plate 634 で はマトリックスき裂がほぼ直線であるのに対して, Plate 611 ではき裂の進展経路がジグザグとなること（Fig. 5， Fig. 6) に対応している.
一方, 四点曲げ試験の圧縮応力ーひずみ線図（Fig. 13） はPlate 634，611 ともにき裂の発生がないためほぼ線形で ある. Plate 611 の初期圧縮ヤング率 $(45 \mathrm{GPa})$ は引張試 験片のヤング率（35 GPa）より高いが, これは圧縮によ り，初期き裂や界面のはく離が閉じたためと考えられる。

また, $\mathrm{AE}$ 特性も損傷進展挙動と相関が見られる.引 張試験における累積 $\mathrm{AE}$ 事象数の変化（Fig. 9）を比べる と, Plate 611 では初期き裂の結合・進展に伴い, 単調 に増加するのに対し, Plate 634 ではき裂の飽和によって 一旦 $\mathrm{AE}$ 事象数の増加率が低下する. Plate 634 の場合, 領域IIで幅全体にわたるき裂の発生に相当する中振幅 $\mathrm{AE}$ が発生するが, Plate 611 の場合, き裂の結合・進展に 相当する低振幅 $\mathrm{AE}$ が発生する. 両試験片ともに破断前 は繊維の引き抜き，破断に相当する高振幅 $\mathrm{AE}$ が発生し ている（Fig. 8)。一方, 曲げ試験における AE は Plate 634，611 ともに連続的に増加しており (Fig. 16)，これ は引張面から中立軸に向かって徐々にき裂が進展してい ること（Fig. 14, Fig.15）を表している.

\section{$4 \cdot 3$ ヤング率・ポアソン比と損傷}

除荷ヤング率はき裂密度とほぼ線形の相関関係にある (Fig. 11). Plate 634 と Plate 611 の初期ヤング率の差 （9.5 GPa）がすべて成形による初期き裂によるものであ ると仮定すると, 初期除荷ヤング率のプロットより， Plate 611 の初期き裂密度が $3.1 / \mathrm{mm}$ と計算される. 従 って, 引張負荷による Plate 611 のき裂の約半分は新しく 発生したものである. Plate 634 の最終除荷ヤング率の 飽和值を除いて, 初期, 最終除荷ヤング率の飽和值は単 調引張応力一ひずみ線図の最終ヤング率より高い.これ は界面における摩擦の影響が考えられる。一方, ポアソ ン比とき裂密度との相関関係は必ずしも明確ではない. Plate 634 ではき裂の増加に伴い, ポアソン比が少し増 加した後, 減少するが, Plate 611 ではき裂に対して敏 感に反応しない（Fig. 12)。従って, 初期除荷ヤング率 は損傷のパラメータとして用いることができるが，ポア ソン比は適当ではない.

\section{5 結}

\section{言}

二種類の CF/BSG の微視構造と機械的特性の関係, 応力ーひずみ線罒・ $\mathrm{AE}$ 特性と破壊メカニズムの関係を 実験的に調べた. 複合材料の微視構造, 初期き裂から機 械的特性が説明できる。応力ーひずみ線図と $\mathrm{AE}$ 特性 (累積事象数, 振幅分布) はき裂の様相・進展挙動と大 きな相関がある。ヤング率はポアソン比と比べて, き裂 密度を評価するよりよい損傷パラメータとなりうる。

\section{参 考 文 献}

1) A. G. Evans and F. W. Zok, J. Mater. Sci., 29, 3857 (1994).

2 ) S. -W. Wang and A. Parvizi-Majidi, J. Mater. Sci., 27, 5483 (1992).

3 ) P. G. Karandikar and T. -W. Chou, Comp. Sci. Tech., 46, 253 (1993).

4 ) D. S. Beyerle, S. M. Spearing, F. W. Zok and A. G. Evans, J. 
Am. Ceram. Soc., 75, 2719 (1992).

5) D. S. Beyerle, S. M. Spearing and A. G. Evans, J. Am. Ceram. Soc., 75, 3321 (1992).

6) I. M. Daniel, G. Anastassopoulos and J. -W. Lee, Comp. Sci. Tech., 46, 105 (1993).

7.) A. Dalmaz, P. Reynaoud, D. Rouby and G. Fantozzi, J. Mater. Sci., 31, 4213 (1996).

8 ) S. M. Bleay, B. Harris, V. D. Scott, R. G. Cooke and F. A. Habib, J. Mater. Sci., 31, 5933 (1996).

9) H. Tsuda, J. Takahashi, K. Kemmochi and R. Hayashi, J. Am. Ceram. Soc., 79, 2293 (1996).
10) K. M. Prewo, J. Mater. Sci., 17, 3549 (1982).

11) N. Takeda, O. Chen, T. Kishi, W. K. Tredway and K. M. Prewo, Engng. Fract. Mech., 40, 791 (1991).

12) N. Takeda, C. Miyasaka and K. Nakata, Nondestr. Test. Eval., 8, 813 (1992).

13) K. Ogi, N. Takeda and K. M. Prewo, J. Mater. Sci., 32, 6153 (1997)

14) J. Aveston, R. A. Mercer and J. M. Sillwood, National Physical Laboratory, Report SI-90-11-98 (1975).

15) J. Aveston and A. Kelly, J. Mater. Sci., 8, 352 (1973).

16) V. Laws, J. Phys. D, 4, 1737 (1971). 